\title{
THE EFFECT OF SCIENCE LEARNING MODEL, ENVIRONMENT, TECHNOLOGY, AND SOCIETY ASSISTED BY ENVIRONMENTAL MEDIA ON SCIENCE KNOWLEDGE COMPETENCE OF GRADE V ELEMENTARY SCHOOL STUDENTS OF SRIKANDI CLUSTER EAST DENPASAR IN ACADEMIC YEAR 2017/2018
}

\author{
Devi, P.S.A. ${ }^{1}$, Jampel, I.N. ${ }^{2}$, Jayanta, I.N.L. ${ }^{3}$
}

${ }^{1}$ Universitas Pendidikan Ganesha, Singaraja, Indonesia ${ }^{2}$ Universitas Pendidikan Ganesha, Singaraja, Indonesia ${ }^{3}$ Universitas Pendidikan Ganesha, Singaraja, Indonesia

\section{A RT I CLE INFO}

Article history:

Received 12 March 2018

Received in revised form 09 April

Accepted 14 May 2018

Available online 25 June 2018

Keywords:

Science Learning Model,

Enviroment,

Technology,

Society,

Competence of science

\begin{abstract}
A B S T R A C T
This study aims to determine the effect of Science Learning Model, Environment, Technology, Society assisted Environmental media on Science Competence of grade $\mathrm{V}$ students. The type of this research was quasi experiment with non-equivalent group design. The population in this study was the entire class V in the Srikandi cluster East Denpasar amounted to 362 students. The sample of this research was class V of SDN 5 Sumerta were 28 students as experimental group and class V of SDN 10 Sumerta were 28 students as control group. Data collected with multiple choice test instruments, then was analyzed using descriptive statistical analysis and inferential statistical analysis (t-test). Based on the data analysis, $\mathrm{t}_{\text {count }}=2.500$ and $t_{\text {tabel }}(5 \%$ significance level $)=2,000$. This means that $t_{\text {count }}=2,500>t_{\text {tabel }}=$ 2,000 . There was a significant difference of science competence between groups of students who was taught by science learning model, Environment, Technology, Society assisted Environmental media and group of students which is learn through conventional learning. The average value of science competence of the experimental group $\left(\bar{X}_{1}\right.$ ) is 79.00 while the mean score of control group students ( $\bar{X}_{1}$ ) is 74.07. This means $\bar{X}_{1}=79,00>\bar{X}_{2}=74,07$, so it can be concluded that the application of learning model of Science, Environment, Technology, Society assisted Environmental media influenced the competence of science. Based on the results of this study it is suggested that the results of this study can be used as a relevant study, especially as supporting the next research.
\end{abstract}

Copyright (C) Universitas Pendidikan Ganesha. All rights reserved.

\section{Introduction}

Education encourages people to be involved in the process in a better direction, develop selfconfidence, develop curiosity and increase the knowledge and skills that they had. Thus education helps to improve the quality of personal and community life. One of the efforts to improve the quality of education is the implementation of Curriculum 2013. Kunandar (2014: 24) states that Curriculum 2013 was developed with the following mindset improvements: 1) teacher-centered learning patterns to learnercentered learning, 2) one-way learning patterns (teacher-student interaction) into interactive learning ( interaction between teacher-students-natural-environment-community, other sources or media, 3) isolated learning patterns into networking learning patterns (learners gain knowledge from anyone and everywhere they could be contacted and obtained through the internet), 4) passive learning patterns being active-looking learning (active learning of learners were strengthened by science learning approaches), 5) self-learning patterns into group learning (team-based), 6) learning patterns of single tools into multimedia-based learning, 7) mass-based learning patterns become customer needs by 
strengthening the development of specific competencies had for every student, 8) the pattern of single science learning becomes plural science, 9) passive learning patterns become critical learning.

Curriculum 2013 was developed on competency-based theories designed to provide the broadest learning experience for students in developing the ability to behave, be knowledgeable, skilled and act at the level of learning in elementary schools (Kosasih, 2016).

Natural Sciences (IPA) is one of the lessons in elementary school that is closely related to everyday human life. Natural Science subjects had function to develop knowledge about the natural environment, develop skills, insights, and technological awareness in relation to their use for daily life. Learning science in principle is not enough just to memorize a concept through textbooks, but more than that learning science is essentially a process and product. This can be done in various ways, such as observing an object or natural phenomenon, taking measurements, testing data, and conducting experiments. As stated by Samatowa (2016: 3) "Natural Science discusses natural phenomena that were arranged systematically based on the results of experiments and observations made by humans".

These activities should be something that encourages the mastery of students' science competencies, so it was expected that teachers could apply these activities optimally. But in reality, in the learning process in elementary schools, especially in the field of natural science there were still many weaknesses found. Students were not active in expressing opinions or ideas, and students were less creative.

Based on observations conducted on January 8, 2017 the minimum completeness criteria (KKM) set in the Srikandi Cluster for science knowledge competency were 73. From observation at Srikandi Cluster Elementary School obtaining in the end-of-semester, the results showed that natural science test of grade V students in academic year 2017/2018 from 362 students who achieved KKM scores were 167 students. So it can be concluded that $54 \%$ of all V grade students in Srikadi cluster had not yet reached the KKM. Based on this, it could be said that the knowledge competence of science of class V students was not yet optimal. Factors that influence this include: students were less active at the time of learning, there were still many students who feel they had not dared to express their opinions or ideas in front of the class and in carrying out Curriculum 2013 the teacher still had difficulty choosing the model and media to be used so that learning becomes less attractive and made students become bored because the models and media applied were still monotonous.

From these problems, it was believed necessary to have innovations in learning, namely learning that prioritizes knowledge competence, student-centered, provides meaningful direct learning experiences, and relevant to real life. One of the innovations was the learning model of Science, Environment, Technology, Society (SETS) assisted by environmental media. "SETS learning model is one of the concepts of meaningful learning for students, because students are invited to directly learn natural science material from the impact of existing technology in the surrounding environment" (Wisudawati, et al., 2017: 72). Learning with the SETS learning model was very suitable to be applied for science learning.

SETS learning model made science learning more interesting, fun, and meaningful because students were given the opportunity to gain knowledge not only from books but by utilizing technology, environment and society. This made learning more effective and enjoyable, so that knowledge received by students was not quickly forgotten. A characteristic feature of this learning model was that there was an introduction to the issues of problems that exist in the community that were explored from students. Apperception in life can also be carried out, namely linking events that have been known by students to the material to be discussed, so that there appears to be continuity of knowledge because it begins with things that students know before which are emphasized in the situation. This is in line with the meaningful learning theory put forward by Ausubel (in Wisudawati, et al., 2017: 43) that "a learner learns by associating with the understanding that already known by students".

Based on this theory, in the science learning process it would be more meaningful if students build concepts that exist within themselves by conducting and associations to experiences, phenomena they encounter, and new facts that would be found in life. Experience, various phenomena, as well as new facts would certainly found many students in the environment. It could be said that the environment played a role in children's growth and development. Teachers were not supposed to do learning in the classroom, but teachers could invite students to learn outside the classroom and use the environment as a learning resource. This is because children will first learn and understand something from their environment (Husamah, 2013).

It was quite similar in learning and understanding concepts and principles in science learning. Learning activities outside the classroom by utilizing the environment were very suitable to be applied in science or natural science subjects. IPA was a subject in elementary school that was intended so that students had knowledge, ideas and concepts that were interrogated about the surrounding environment. Therefor by using environmental media, students become easier to understand about the surrounding 
environment. The use of the environment as a medium in natural science learning can help students to more easily associate events that have been known by students with the material to be discussed.

Based on the descriptions that have been presented, the SETS learning model was tested by assisting environmental media on the science knowledge competence by carrying out a research entitled "The Effect of Science Learning Model, Environment, Technology, Society assisted by Environmental Media on Science Knowledge Competence of Grade V Elementary School Students of Srikandi Cluster East Denpasar in Academic Year 2017/2018".

The purpose of this study was to describe the science competence of students who were taught by the SETS learning model with environmental media in the fifth grades students of Srikandi cluster of Elementary School in East Denpasar District in the academic year 2017/2018. To describe the science knowledge competence of students who were taught with conventional learning in the fifth grades students of Srikandi cluster of Elementary School, East Denpasar District in academic year 2017/2018. To find out the effect of SETS learning model assisted by environmental media on science knowledge competencies for fifth grade students of SD Gugus Srikandi, East Denpasar District in academic year $2017 / 2018$.

\section{Methods}

This research was conducted in the fifth grade of SD Negeri Gugus Srikandi, East Denpasar Subdistrict. The design of this research was quantitative research with the research design used, namely quasi-experimental design with the Nonequivalent Control Group Design form. This design consists of two groups, namely the experimental group and the control group. The group both obtained pretest and posttest.

The population of this study was all grades V SD Gugus Srikandi in East Denpasar, which were scattered in six public elementary schools as many as 362 students. The sample is "a portion of the population taken, which is considered to represent the entire population and taken using certain techniques" (Agung, 2014: 69) ". While Sugiyono (2016: 118) states that "the sample is part of the number of characteristics possessed by the population". In addition of the sample is part or representative of the population under study (Arikunto, 2015). So, it can be concluded that the sample is part of the amount owned by the population

In sampling method, this study used the Random Sampling technique, which the class randomized to, so that each class got the same opportunity to become a research sample. (Sugiyono, 2015: 132) states that "Random sampling is a random sampling method."

Sugiyono (2015: 132) states that "Random sampling is the way of the samples took randomly". Thus, in this study each class got the same opportunity to be sampled. The method used to determine the sample by giving a serial number to each school in the Srikandi cluster and then drawing. After getting the lottery results, the pretest was given for class equalization. Then proceed with determining the experimental class and control class. To test sample equality, matching techniques were used. Matching is a technique to homogenize groups on a variable or more that has been identified as having a close relationship with the appearance of non-independent variables (Darmadi, 2011). After getting the pretest value from the sample, then the value was analyzed by matching technique. The way to equalize by matching the pretest scores of students from both groups in the sample. This was done by sorting the grades of students from the highest to the lowest then the same value will be one pair

The method used for data collection was using tests. The instrument used was an objective test. The objective test form was multiple choice which includes four answer choices (a, b, c, or d). The measured competency of knowledge consists of remembering (C1), understanding (C2), applying (C3), and analyzing (C4) with the dimensions of knowledge; especially in elementary school is factual and conceptual knowledge. testing instrument research, namely validity test, reliability test, different power test, and level of difficulty

Data analysis techniques used were descriptive and inferential statistics. Inferential statistics included parametric and non-parametric statistics. Descriptive statistics are a way of describing data collected using statistical formulas. "Descriptive statistics are a method of data processing carried out by applying descriptive statistical formulas to describe a particular object / variable, so that general conclusions can be obtained" (Agung, 2014: 110). Inferential statistics are "inferential statistical analysis is a statistical technique used to analyze sample data and the results are applied to the population" (Sugiyono, 2016: 209). The results of the posttest value would be analyzed using parametric statistical analysis namely t-test. Before carrying out the analysis using the t-test, first perform the analysis prerequisite test, namely the data normality test and variance homogeneity test. 
The research hypothesis would be tested, namely: There is no significant difference in science knowledge competencies between groups of students who are taught using Science, Environment, Technology and Society assisted by environmental media with groups of students who are taught using conventional learning in fifth grade students of Gugus Srikandi East Denpasar in Academic Year $2017 / 2018$.

\section{Findings and Discussion}

The results of this study describe the average value (mean), standard deviation, and variance of the score gain data normalized science knowledge competence. The data obtained in this study were grouped into two, namely: experimental group science knowledge competency data and control group science knowledge competency. The data obtained from the ordinary multiple choice tests with 4 answer choices. Knowledge competency test for science conducted after 6 treatments. The total numbers of the student in the experimental group was 28 students and control group was 28 students.

The results of this study indicate that the science knowledge competencies achieved by students who learn to use the SETS learning model assisted by environmental media were different from students who learn with conventional learning.

The average value of students' science knowledge competencies for the experimental class that was taught using the SETS learning model with 79.00 environmental media assisted with a variance of 53.33 and a standard deviation of 7.23. While the average value of students' science learning outcomes for the control class that was taught using conventional learning was 74.07 with a variance of 55.81 and a standard deviation of 7.47.

From these data, it showed that the science knowledge competencies of the experimental class students who were taught using the SETS Assisted by Media Environment learning model had a higher average value than the control class which was taught using Conventional learning. The following is a table describing the science knowledge competencies of class students

Table 1. Description of Mastery of Science Knowledge Comprehension Experiment and Control Group

\begin{tabular}{ccc}
\hline The result of Analysis & Experimental Group & Control Group \\
\hline Average & 79,00 & 74,07 \\
Variant & 53,33 & 55,81 \\
Standard Deviation & 7,23 & 7,47 \\
\hline
\end{tabular}

The data on the mastery of science knowledge competencies in the experimental group and control group were presented in the histogram frequency distribution of science knowledge competencies as follows.

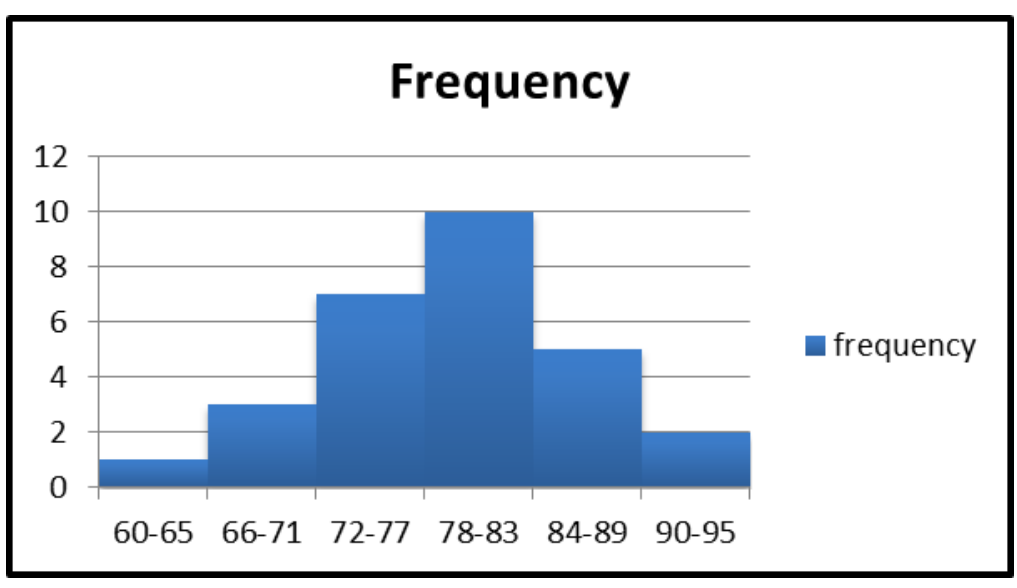

Figure 1. Histogram of Science Knowledge Competency of Experimental Group Results

From the histogram of the science knowledge competency students in the experimental group can be concluded that students who obtained grades in the 60-65 interval class was 1 person, students in the 66-71 interval class were 3 people, who were in the 72-77 interval class were 7 people, students in the 78- 
83 interval class totaled 10 people, students in the 84-89 interval class were 5 people, and students in the 90-95 interval class were 3 people.

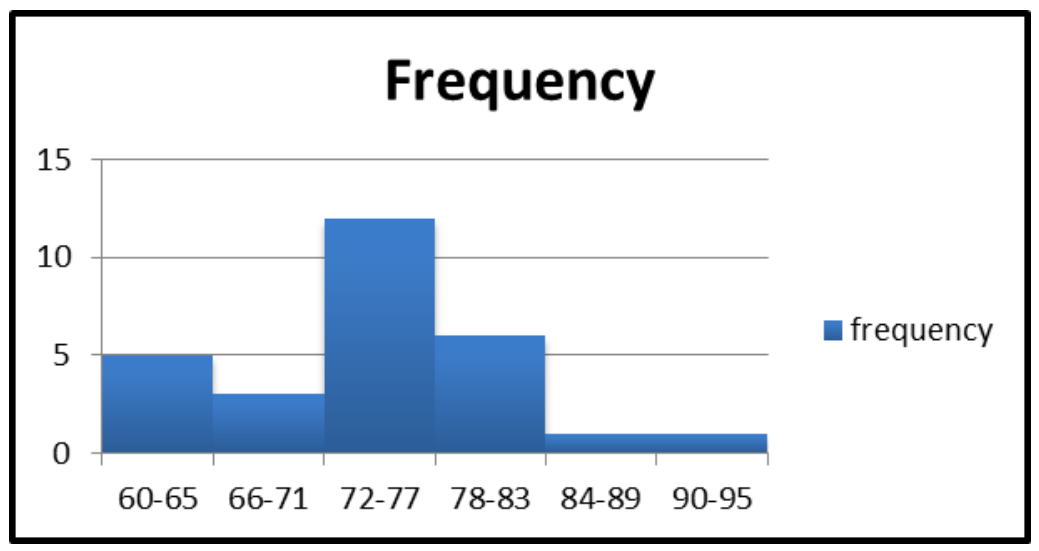

Figure 2. Histogram of Science Knowledge Competency of Control Group

From the histogram of the science knowledge competency students in the control group can be concluded that students who obtained grades in the 60-65 interval class were 5 people, students in the 66-71 interval class were 3 people, who were in the 72-77 interval class were 12 people, students in the 78-83 interval class totaled 6 people, students in the 84-89 interval class was 1 person, and students in the 90-95 interval class was 1 person.

The data obtained from this study were analyzed using statistics through stages which included test data distribution normality, variance homogeneity test, and hypothesis testing. Based on the analysis, the results of the normality distribution of data using the Chi-Square formula showed that the science competence of students in the experimental group at a significant level of $5 \%$ and $\mathrm{dk}=5 \mathrm{had}\left(X_{\text {tabel }}^{2}=\right.$ 11.07). and $\left(X_{\text {count }}^{2}=4.742\right)$ this means that $X_{\text {count }}^{2}<X_{\text {tabel }}^{2}$ then the science knowledge competence in the experimental group was normally distributed. Whereas, in the science knowledge competence of students in the control group at a significant level of $5 \%$ and $\mathrm{dk}=5$ has $\left(X_{\text {tabel }}^{2}=11.07\right)$ and $\left(X_{\text {calculate }}^{2}=1.860\right)$, this means that $X_{\text {count }}^{2}<X_{\text {tabel }}^{2}$ then knowledge competency data. The control group's science was also normally distributed. Based on the data distribution normality test, it was evident that the knowledge competence of science students in the experimental group and the control group was normally distributed

Then homogeneity test was conducted to find out that the data distribution of both groups was homogeneous. Homogeneity of the variance in the data of science knowledge competency was analyzed by $\mathrm{F}$ test. The results of the analysis obtained $\mathrm{F}_{\text {count }}=1.06$ and $\mathrm{F}_{\text {table }}=1.88$. This means that $\mathrm{F}_{\text {count }}<\mathrm{F}_{\text {table }}$ So that the data of both groups have homogeneous variance

The hypothesis tested in this study was that there were no significant differences in science knowledge competencies between groups of students who were taught using Science, Environment, Technology, Society learning models assisted by environmental media and groups of students who were taught through conventional learning in grade V elementary school Srikandi cluster East Denpasar. Statistical analysis used to test the hypothesis in this study was the test with the polled variance formula. Testing criteria is if $t_{\text {count }}>t$ table then Ho was rejected. The table was obtained from the $t$ distribution table at a significance level of $5 \%$ with degrees of freedom $(\mathrm{dk})=n 1+n 2-2$. The results of the t-test analysis of science knowledge competencies were presented in Table 2.

Table 2. The results of the t-test analysis of science knowledge competencies

\begin{tabular}{|c|c|c|c|c|c|c|c|c|}
\hline No & Sample & $\mathbf{n}$ & Dk & $\overline{\bar{X}}$ & $\mathbf{V}$ & $t_{\text {count }}$ & $t_{\text {teifleI }}$ & Explaination \\
\hline 1. & Experimental Group & 28 & 54 & 79,00 & 52,33 & \multirow[t]{2}{*}{2,500} & \multirow[t]{2}{*}{2,000} & \multirow[t]{2}{*}{$H_{\Omega}$ rejected } \\
\hline 2. & Control Group & 28 & & 74,07 & 55,81 & & & \\
\hline
\end{tabular}

Based on the hypothesis test obtained $\mathrm{t}_{\text {count }}=2,500$ with $\mathrm{dk}=28+28-2=54$ and a significance level of $5 \%$ obtained the value of $t_{\text {tabel }}=2,000$ so that $t_{\text {count }}=2,500>t_{\text {tabel }}=2,000$ then Ho was rejected and Ha was accepted. This means that there were significant differences in science knowledge competencies between groups of students who were taught using Science, Environment, Technology, Society learning models assisted by environmental media and groups of students who were taught through conventional learning in fifth grade students of Srikandi cluster Elementary School in East Denpasar. 
From the acquisition of knowledge competencies in both groups, it can be seen that the two groups who initially had equal ability, then after being given treatment in the experimental group with SETS learning model assisted by environmental media, while the control group was not given treatment, the acquisition of science knowledge competency values was different. Competence of students' science knowledge in the experimental group was better when compared to science knowledge competencies of students in the control group. This was due to the learning applied in the experimental group has many advantages. There was the significant differences in science knowledge competencies between the experimental group and the control group because the experimental group was given treatment while the control group was not given treatment at the time of learning. The experimental group was given the treatment in the form of SETS learning model assisted by environmental media having an average value higher than the control group that applied conventional learning.

\section{Conclusion}

Based on the results of the analysis using the t-test with $\mathrm{dk}=54$ at a significance level of $5 \%$, obtained $t_{\text {count }}=2,500>t_{\text {tabel }}=2,000$. This means that there was a significant difference in science knowledge competency between the fifth grades students at SD Gugus Srikandi Denpasar Timur in Academic Year 2017/2018 who taugh using SETS learning models assisted by environmental media and students who taught using conventional learning on the environmental theme of our friends.

The suggestions that could be conveyed based on the results of research that has been done were: the teachers need to be more creative to provide facilities in the form of learning resources and gave opportunities for students in learning by using SETS learning models assisted by environmental media to be meaningful and enjoyable learning for students. For principals to be able to use the results of this study as a support for teacher learning resources in improving the quality of learning by creating encouraging learning in schools so that schools are able to produce students who have quality output. And for other researchers, the results of this study were used as references to carry out further research or find innovations in other learning activities that were meaningful and enjoyable for students.

\section{References}

Agung, A.A Gede. (2011). Pengantar Evaluasi Pendidikan. Singaraja: Universitas Pendidikan Ganesha. Agung, A.A Gede. (2014). Metodelogi Penelitian Pendidikan. Malang: Adiya Media Publishing.

Agung, A.A Gede. (2016). Statistika Dasar Untuk Pendidikan. Yogyakarta: Deepublish.

Arikunto, Suharsimi. (2015). Dasar-Dasar Evaluasi Pendidikan. Jakarta: Bumi Aksara.

Dantes, Nyoman. (2014). Analisis Dan Desain Eksperimen. Singaraja: Universitas Pendidikan Ganesha.

Dantes, Nyoman. (2016). Statistika Nonparametrik. Singaraja: UNDIKSHA Press.

Darmadi, Hamid. (2011). Metode Penelitian Pendidikan. Bandung: Alfabeta.

Daryanto, (2014). Pembelajaran Tematik Terpadu, Terintegrasi (Kurikulum 2013). Yogyakarta: Gava Media.

Husamah, (2013). Pembelajaran Luar Kelas Outdoor Learning. Jakarta: Prestasi Pustakaraya.

Kosasih. (2014). Strategi Belajar dan Pembelajaran. Bandung: Yrama Widya.

Kunandar. (2014). Penilaian Auntentik (Penilaian Hasil Belajar Peserta Didik Berdasarkan Kurikulum 2013). Jakarta: Rajawali Persada.

Murniati, Diani Rachmanita. (2017). Peningkatan Kemampuan Merancang Pembuktian Hipotesis Dalam Pembelajaran Menggunakan Pendekatan Saintifik Dengan Pemberian Tugas Awal. Jurnal Pendidikan Kimia Indonesia, 1(2), p.

Poedjiadi, Anna. (2010). Sains Teknologi Masyarakat. Bandung: Remaja Rosdakarya.

Rismayanti, Ni Made Eny. 2015. Pengaruh Pendekatan Saintifik Berbantuan Media Lingkungan terhadap Hasil Belajar IPA Siswa Kelas V SD Gugus VIII Kecamatan Sawan. e-journal PGSD Universitas Pendidikan Ganesha, 3(1), p.

Samatowa, Usman. (2016). Belajar IPA di Sekolah Dasar. Jakarta: Permata Puri Media. 
Setyosari, Punaji. (2015). Metode Penelitian Pendidian dan Pengembangan. Malang: Prenada Media Group. Sudijono, Anas. (2011). Pengantar Evaluasi Pendidikan. Jakarta: PT. Raja Grafindo Persada.

Sugiyono, (2015). Metode Penelitian Pendidikan Pendekatan Kuantitatif, Kualitatif, dan R\&D. Bandung: Alfabeta.

Sugiyono, (2016). Metode Penelitian Pendidikan Pendekatan Kuantitatif, Kualitatif, dan R\&D. Bandung: Alfabeta.

Sugiyono. (2016). Metode Penelitian Pendidikan. Bandung: Alfabeta.

Suyatno, (2009). Menjelajah Pembelajaran Inovatif. Surabaya: Masmedia Buana Pustaka.

Uno, Hamsah B dan Nurdin Mohamad. (2015). Belajar Dengan Pendekatan Pailkem. Jakarta: PT Bumi Aksara.

Poedjiadi, Anna. (2010). Sains Teknologi Masyarakat. Bandung: Remaja Rosdakarya

Widiani, Ni L. Rai. (2017). Pengaruh Model Pembelajaran Sets Berbantuan Media Audio Visual Terhadap Kompetensi Pengetahuan Ipa Siswa Kelas V. e-journal PGSD Universitas Pendidikan Ganesha, 5(2), p

Wisudawati, Asih Widi dan Eka Sulistyowati. (2017). Metodelogi Pembelajaran IPA. Jakarta: Bumi Aksara. 